\title{
The Effect of Exercise Using Grasping on Shoulder Muscle Activity and Muscle Thickness of Patients with Rotator Cuff Repair
}

\author{
Eun-Young Choi ${ }^{1}$, Hyun Choi ${ }^{2}$ \\ 'Department of Physical Therapy, Gwangyang Health College, Gwangyang; ${ }^{2}$ Department of Physical Therapy, Mokpo Mirae Hosipital, Mokpo, Korea
}

Purpose: This study intended to mediate shoulder exercise using grasping and investigate examine how its effects on affects activities of the shoulder surrounding muscles of the shoulder and thickness of shoulder muscle to suggest effective exercise for patients with rotator cuff repair to return to daily life.

Methods: This study has been done targeteding male patients more than 6 weeks after having En-masse Suture Bridge Technique as rotator cuff repair of the right shoulder, aged 40 to 55 in a medical institution located in Jeollanam-do. Experimental group I $(n=15)$ was selected for a conducting common exercise therapy program and Experimental group II $(n=15)$ was selected for an conducting exercise therapy program using grasping. \%RVC was measured by surface electromyography and muscle thickness was measured by ultrasound before mediation to for analysisze of before and after results within group and between groups.

Results: In comparison of change of \%RVC, Tthere were meaningful differences in only posterior deltoid and infraspinatus in comparing a change of \%RVC within experimental group I $(p<0.001)$. and Tthere were meaningful differences in both supraspinatus and infraspinatus in muscle thickness within experimental group I $(p<0.001)$. In comparison of change of $\% R V C$, Tthere were meaningful differences in anterior deltoid, posterior deltoid and infraspinatus in comparing a change of \%RVC within experimental group II $(p<0.05)(p<0.01)$ $(p<0.001)$, and there were meaningful differences in both supraspinatus and infraspinatus in muscle thickness within experimental group II ( $p<0.001)$. In comparison of change of \%RVC between groups, Tthere was a meaningful difference in only posterior deltoid in comparing a change of \%RVC between groups $(p<0.001)$.

Conclusion: We found that exercise therapy using grasping has a positive effect on shoulder stability muscles such as supraspinatus muscle and infraspinatus muscle and activity of deltoid muscle.

Keywords: Rotator cuff repair, Grasping, Shoulder muscle activity

\section{서 론}

인간의 일상생활동작을 수행하는데 손의 기능은 반드시 필요하 며, 이와 더불어 일생생활동작을 위해 어깨관절의 능동적 관절운동 범위와 근력, 지구력, 피로에 대한 저항 능력 등이 필요하다.' 어깨관 절이 손상되면 먹기, 씻기 등과 같은 일상생활을 수행하는데 어려움 을 호소하게 된다. ${ }^{2}$ 어깨관절 손상은 유착성어깨관절낭염, 어깨충돌 증후군, 근막통증증후군, 어깨 돌림근띠 파열 등이 원인이 되며, 특히 어깨 돌림근띠 손상은 근골격계 질환 및 레져 활동 인구 증가로 그 유 병율이 증가하고 있는 추세이고, ${ }^{3}$ 이렇게 발생되는 어깨 돌림근띠 파 열들은 일반적으로 부분 혹은 완전 손상으로 발생 되어 기능적인 측

Received Jan 18, 2016 Revised Feb 19, 2016

Accepted Feb 22, 2016

Corresponding author Hyun Choi

E-mail enthusiasm74@naver.com
면으로는 40 세 이후부터 증가하기 시작한다. ${ }^{4}$

어깨 돌림근띠의 손상은 어깨관절의 벌림, 회전 그리고 위팔어깨 의 안정성을 유지하는 주된 기능에 악영향을 미치며, 특히 위팔어깨 의 힘줄 염좌나 움직임 제한, 주변부위의 액체 유출, 그리고 근부하의 불균형 등과 같은 특성들에 의해 다양한 형태의 역학적 손상을 보이 고 있다. ${ }^{5}$ 이렇게 발생되는 손상기전은 독립적으로 판단하기 보다는 다양한 원인들로 인해 동시에 발생되거나 또는 단계적으로 작용하여 병적인 상태로 진행되며, ${ }^{6}$ 이는 어깨관절의 고정이나 약물 등의 치료 로 재생되거나 자연경과로 치유되기가 어려워 일시적으로 통증이 감 소하더라도 점진적인 근력 약화가 동반되기도 한다. 근례에 들어 어 
깨 돌림근띠 손상 후 발생하는 관절증을 치료하기 위해 관절경하 최 소 간헐적 봉합술 및 관절경하 봉합술 등의 수술 기법들이 이용되고 있으며, ${ }^{8}$ 통증을 줄이고 움직임과 기능의 회복에 높은 신뢰를 보여 주고 있으나, ${ }^{9}$ 수술 후 관절낭의 단축에서 오는 어깨관절의 수동적 움직임 제한과 근력의 약화에서 오는 능동적 움직임 제한 등이 흔히 발생된다. ${ }^{10}$ 이러한 합병증을 줄이고 재파열을 방지하기 위해 임상에 서 많은 재활방법들이 시행되고 있지만, 관절경 수술 후에 고전적 재 활지침에 따라 재활을 수행해도 수술 환자 $4.9 \%$ 에서는 필연적으로 관절 경직이 발생된다고 보고 하였다. ${ }^{11}$ 관절경직은 점진적인 기능감 소를 유발하고 관절낭의 구축으로 인해 어깨관절의 모든 관절가동 범위에서 나타나며 특히 머리 위로 손을 가져가는 업무나 등뒤로 손 을 가져가는 활동들에 있어서의 어려움을 나타낸다. ${ }^{12}$ 따라서 기능적 제한을 회복시키기 위해 어깨에 대한 구조의 이해를 바탕으로 기능 제한에 대한 원인의 탐구와 이를 기초로 한 치료를 시행해야 한다. ${ }^{13}$

좋은 재활프로그램은 수술 후 환자가 기능적 활동과 삶의 질을 빠 른 시간 안에 되돌릴 수 있는 것이다. ${ }^{14}$ 이를 위해 어깨 재활의 치료지 침은 초기 6 주 동안은 재건한 힘줄의 손상을 줄이기 위해 능동적 움 직임을 제한하고 이후 점차 열린 사슬과 닫힌 사슬을 이용하여 근육 들의 기능회복에 초점을 맞춰 시행해야 한다고 권고 하고 있으며, 힘 줄과 뼈의 확실한 치유가 확인되면 시행해야 한다는 견해가 일반적 이다..$^{5}$ 또한 복원술 후 어깨 돌림근띠 근기능이 약화됨으로 움직임 수행 시 근육작용의 불균형이 일어날 수 있고 이를 보상하기 위하여 이차적인 압박이나 장력이 가해질 수 있기 때문에 이런 현상을 피하 기 위해 근력 강화의 필요성 또한 제시되고 있다. ${ }^{16}$ 복원술 후 운동 중 에서 어깨의 심부 근육들의 활성도를 높일 수 있는 방법으로 쥐기 (hand grasp) 운동은 수술 부위에 부하를 크게 전달하지 않으며 근육 의 긴장도를 증가 시킬 수 있는 중재방법이다. ${ }^{17}$ 손에 부하가 가해질 경우 삼각근과 같은 어깨 거상근육에 비해 어깨관절의 안정성에 관 여하는 어깨돌림띠 근육, 특히 가시아래근에서 근활성도의 변화가
더욱 두드러진다고 하였는데, 수의적인 쥐기 힘이 증가 하는 동안 세 모근들의 활성도가 줄어드는 반면 가시아래근의 참여도는 증가한다 고 하였다. ${ }^{18}$

본 연구는 이러한 쥐기의 특성을 사용하여 어깨운동을 중재한 후 어깨주변근육의 활성도와 근두께에 미치는 영향을 알아봄으로써 향 후 어깨 돌림근띠 복원술 환자의 조기 일상생활 복귀를 위한 효율 적인 운동방법을 제시하고자 한다.

\section{연구방법}

\section{1. 연구기간 및 대상}

본 연구는 2014년 10월부터 2015년 5월까지 8개월간, 전라남도에 소재 한 의료기관에서 오른쪽 어깨 돌림근띠 복원술을 일체(En-masse) 교 량형 봉합술로 받은 40-55세 연령범위의 남성 환자들로, 연구 대상자 선정 기준은 어깨 돌림근띠 부분파열 $(3 \mathrm{~cm}$ 미만)을 진단 받고 어깨 돌림근띠 복원 수술을 받은 지 6주가 지난 환자로, 본 연구에 영향을 미칠 수 있는 다른 근골격계 또는 신경계질환이 없는 자로 선정하였 으며, 병원 인근에 거주하여 퇴원 후에도 외래로 꾸준히 중재를 받을 수 있는 자, 본 연구를 충분히 이해하고 동의한 30 명을 표본 추출하 여 실험군I과 실험군II에 각각 15 명씩 무작위로 배치하였다.

\section{2. 연구설계}

본 연구는 어깨 돌림근띠 복원술을 받고 6 주가 지난 남성 환자들을 대상으로 일반적 운동치료 프로그램을 중재한 집단을 실험군I로, 쥐기를 활용한 운동치료 프로그램을 중재한 집단을 실험군표로 설정 한 후, 4 주간, 주 4 회, 1 일 1 회, 1 회 40 분간 중재하여, 중재 전 표면근전 도로 $\% \mathrm{RVC}$ 를 측정하였고, 초음파로 근두께를 측정하였고 4 주 중재 후 다시 \%RVC와 근두께를 재 측정하여 집단 내 전후 비교와 집단 간 분석을 실시하였다.

Table 1. General exercise program on 1-4 weeks

\begin{tabular}{|c|c|c|c|c|}
\hline \multicolumn{3}{|c|}{ General exercise program on 1-2 weeks } & \multicolumn{2}{|c|}{ General exercise program on 3-4 weeks } \\
\hline Position & Stretching & Strengthening` & Stretching & Strengthening \\
\hline Standing & $\begin{array}{l}\text { Pendulum } \\
\text { External rotation } \\
\text { Behind the back internal } \\
\text { rotation }\end{array}$ & & $\begin{array}{l}\text { Pendulum } \\
\text { External rotation } \\
\text { Behind the back internal rotation } \\
\text { Wall slide stretch }\end{array}$ & $\begin{array}{l}\text { Forward flexion } \\
\text { Sub-maximal isometric exercise: } \\
\text { internal and external rotation at neutral }\end{array}$ \\
\hline Supine & $\begin{array}{l}\text { Passive arm elevation } \\
\text { External rotation with } 90^{\circ} \\
\text { abduction cross-chest stretch }\end{array}$ & & $\begin{array}{l}\text { External rotation } \\
\text { Passive arm elevation } \\
\text { External rotation with } 90^{\circ} \text { abduction } \\
\text { Cross-chest stretch }\end{array}$ & \\
\hline Sidelying & & External rotation & & \\
\hline Prone & & $\begin{array}{l}\text { Horizontal arm raises, "t" rowing, } \\
\text { scaption "y" }\end{array}$ & & \\
\hline
\end{tabular}




\section{3. 중재방법}

\section{1) 일반적 운동치료}

일반적 운동치료는 미국스포츠의학 협회에서 제시한 객관화된 지침 을 사용하였으며, 1 단계 강화 운동 후 실시하는 2 단계 강화 운동 단계 로 주로 치료사나 보조 기구를 이용한 능동보조운동을 실시하였고, 저항성 견갑골 강화 운동과 어깨 돌림근띠와 어깨세모근에 대한 운 동을 주로 시행하였으며, 수행 되는 모든 운동은 통증이 없는 범위에 서 실시하였다(Table 1). 신장운동은 각 동작 간 1 회씩 3set 로 실시하 였고, 근력운동은 $1 \mathrm{set}$ 당 6 회씩 $3 \mathrm{set}$ 를 1 주일에 4 회 실시하였다. 그리 고 운동 간 피로를 방지하기 위해 휴식시간은 set 당 1-2분의 휴식을 갖게 하였으며, 운동 후에 통증을 조절하기 위해 Icing 15분, TENS 15 분을 적용하였다.

\section{2) 쥐기를 활용한 운동치료}

대상자들의 쥐기 운동중량을 결정하기 위해 악력계를 사용하여 파 악력 1RM (Repeated maximum)을 측정한 후, 측정값을 토대로 훈련 중량은 $1 \mathrm{RM}$ 의 $30 \%$ 로 설정하였다. 일반적 운동치료 중재에서 근력 강화의 동작 전에 악력계를 사용하여 쥐기를 $1 \mathrm{RM}$ 의 $30 \%$ 중량으로 쥔 후 일반적 운동치료의 운동 과정을 수행하였고, ${ }^{19}$ 운동을 시행하 는 동안 악력계의 수치를 지속적으로 확인하여 시각적 feedback을 활 용한 운동을 실시하였으며, ${ }^{20}$ 신장운동은 각 동작 간 1회씩 $3 \mathrm{set}$ 로 실 시하였고, 근력운동은 1 set 당 6 회씩 $3 \mathrm{set}$ 를 1 주일에 4 회 실시하였다. 그리고 운동 간 피로를 방지하기 위해 휴식시간은 set 당 1-2분의 휴식 을 갖게 하였으며, 운동 후에 통증을 조절하기 위해 Icing 15 분, TENS 15 분을 적용하였다.

\section{4. 측정방법}

1) 어깨주변 근활성도 측정

(1) 표면근전도 전극 부착

어깨주변 근육의 근활성도를 측정하기 위해 표면 근전도 MP 150 system (Biopac, USA) 5채널을 사용하였으며, 근전도 신호 수집을 위한 표본 추출율(sampling rate)은 1,000 으로 하였고, 주파수 대역 필터는 20-450 Hz로 하였다. 앞어깨세모근, 뒤어깨세모근, 가시위근, 가시아 래근 그리고 위등세모근의 근전도 신호를 수집하기 위한 전극 부착 방법 및 부위는 다음과 같다.

근전도 신호의 피부저항을 최소화하기 위해 대상자들의 피부에서 털을 제거하고 가는 사포를 이용하여 각질을 제거한 뒤 알코올 솜으 로 문질러 피부를 청결히 한 후, $\mathrm{Ag} / \mathrm{Agcl}$ 표면 전극을 사용하여 앞어 깨세모근은 어깨봉우리에서 손가락 2-3개 정도 아래 근복 위 근섬유 방향으로 부착하였고, 뒤어깨세모근은 어깨봉우리에서 후부쪽으로 손가락 2-3개 정도 뒤에 부착하였다. 가시위근은 어깨뼈 가시돌기의
외측 원위부를 촉지하여 어깨뼈 가시위돌기에 부착하였으며, 가시아 래근은 어깨뼈 가시돌기를 촉지하고 이와 평행하게 외측연으로부터 $4 \mathrm{~cm}$ 정도 가시아래돌기에 부착하되 어깨세모근 후부섬유를 피해서 부착하였다. 위등세모근은 제 7 목뼈 가시위 돌기와 빗장뼈 원위부 사 이 $1 / 3$ 지점에 부착하였고, 접지전극은 가까운 돌출부위에 부착하였 으며, 모든 전극은 $2 \mathrm{~cm}$ 간격으로 근섬유와 평행하게 부착하였다.

\section{(2) \%RVC 측정}

$\% \mathrm{RVC}$ 측정은 우선 특정 동작을 기준으로 정규화(Normalizing)하기 위해 기준동작 시 RMS값과 특정 동작 시 RMS를 측정하였다. 기준 동작 시 Root Mean Square (RMS)는 악력계를 자연스럽게 쥐고, 어깨 관절 $90^{\circ}$ 팔꿉관절 폄 상태에서 5 초 동안 유지할 때 앞어깨세모근, 뒤 어깨세모근, 가시위근, 가시아래근 그리고 위등세모근의 근전도 신호 를 수집하여, 앞 1 초 구간과 뒤 1 초 구간을 제거 하고 3 초 구간의 RMS 값을 구하였고, 이를 3 회 반복 측정하여 평균값을 측정하였다. 특정 동작 시 RMS는 기준 동작과 동일한 자세에서 악력계를 최대의 힘으 로 5 초 동안 쥐게 하여 앞어깨세모근, 뒤어깨세모근, 가시위근, 가시 아래근 그리고 위등세모근의 근전도 신호를 수집하였으며, 앞 1 초 구 간과 뒤 1 초 구간을 제거 하고 3 초 구간의 RMS값을 구하였고 이를 같은 방법으로 3 회 반복 측정하여 평균값을 측정하였다. 매 측정마 다 충분한 휴식을 취한 후 측정하였으며, 동작 시간의 균일화를 위해 동작 시 메트로놈을 켜놓고 사전에 충분한 연습을 통해 시간 내에 동 작을 실시하도록 하였다. 이렇게 수집된 근전도 신호들은 특정동작 시 RMS 평균값을 기준동작 시 RMS 평균값으로 나눠 백분율 하여 $\% \mathrm{RVC}$ 값을 구하였으며, 근전도 신호 분석은 Acqknowledge 3.8 .1 software program (Biopac, USA)를 사용하였다.

\section{2) 가시위근과 가시아래근의 두께 측정}

근육의 구조변화를 측정하기 위해 범용 초음파 영상 촬영장치(Acuson X300PE, Siemens Co., Germany)를 사용하여 가시위근과 가시아 래근의 두께를 측정하였다. 사용된 변환기는 VF1 선형변환기(Liniear transducer)로 장치의 주파수 변조 범위는 3-5 MHz이고 gain 범위는 20-80이다. gain (G50)과 focus $(4.5 \mathrm{~cm})$ 는 고정시켜 모든 검사에 동일하 게 적용하였다. 측정 자세는 팔걸이 의자에 편하게 앉아 팔걸이에 팔 을 올려놓아 아래팔 부위를 고정하여 상지를 이완시킨 후 측정하였 다. 가시위근을 검사하기 위해 견갑가시에서 상부 $2.5 \mathrm{~cm}$, 내측모서리 에서 $2.5 \mathrm{~cm}$ 에서 횡주사(transverse measurement)를 하였으며, 가시아 래근을 검사하기 위해 어깨가시에서 하방 $5 \mathrm{~cm}$, 내측모서리에서 2.5 $\mathrm{cm}$ 에서 횡주사로 평면형 프로브(Linear Pro be)를 사용하여 검사하 였다. ${ }^{21}$ 획득한 영상은 컴퓨터 영상저장 및 전송 프로그램인 picture achiving and communication system (PACS)의 caliper를 사용하여 두께 
를 분석하였다.

\section{5. 자료분석}

자료분석 방법은 Window용 SPSS 18.0 을 이용하여 연구대상자의 일 반적 특성을 Shapiro-wilk로 정규성 검정하였다. 어깨주위 근활성도 와 근두께의 집단 내 변화비교는 대응표본 t-검정(Paired t-test)을 사 용하였으며, 사전 검사값을 통제하기 위해 공변량을 사전검사로 설 정 후 집단 간 사후 검사값으로 공분산분석(ANCOVA)을 시행하였 고, 유의 수준은 $\alpha=0.05$ 로 설정하였다.

\section{결 과}

\section{1. 연구대상자들의 일반적 특성}

실험집단 간 키, 나이, 몸무게, 그리고 앞어깨세모근, 뒤어깨세모근, 가

Table 2. Characteristic of subjects

\begin{tabular}{lcccccc}
\hline Items & $\begin{array}{c}\text { Experimental } \\
\text { group I } \\
(\mathrm{n}=15)\end{array}$ & & $\begin{array}{c}\text { Experimental } \\
\text { group II } \\
(\mathrm{n}=15)\end{array}$ & $\mathrm{t}$ & $\mathrm{p}{ }^{*}$ \\
\cline { 2 - 3 } & $\mathrm{M} \pm \mathrm{SD}$ & & $\mathrm{M} \pm \mathrm{SD}$ & & \\
\hline Age & $52.5 \pm 5.3$ & & $50.1 \pm 5.3$ & 1.823 & 0.389 \\
Hight & $166.5 \pm 6.7$ & & $164.3 \pm 5.9$ & 1.487 & 0.413 \\
Weight & $64.2 \pm 9.8$ & & $66.4 \pm 8.2$ & -0.642 & 0.174 \\
Deltoid Anterior \%RVC & $94.6 \pm 9.5$ & & $100.8 \pm 15.5$ & -0.725 & 0.181 \\
Deltoid Posterior \%RVC & $100.0 \pm 15.5$ & & $110.6 \pm 18.3$ & -0.531 & 0.126 \\
Supraspnatus \% RVC & $99.6 \pm 14.7$ & & $106.8 \pm 12.4$ & -0.692 & 0.182 \\
Infraspinatus \%RVC & $122.4 \pm 20.5$ & & $129.0 \pm 23.4$ & -0.351 & 0.712 \\
Trapezius Upper \%RVC & $103.6 \pm 18.4$ & & $105.1 \pm 20.2$ & -0.078 & 0.921 \\
\hline
\end{tabular}

*Shapiro-wilk.

Table 3. Change in \%RVC and muscle thickness within experimental group I

\begin{tabular}{|c|c|c|c|c|c|}
\hline & & \multicolumn{2}{|c|}{ Experimental group I $(n=15)$} & \multirow[b]{2}{*}{$\mathrm{t}$} & \multirow[b]{2}{*}{$\mathrm{p}$} \\
\hline & & $\begin{array}{l}\text { pre-test } \\
\mathrm{M} \pm \mathrm{SD}\end{array}$ & $\begin{array}{l}\text { post-test } \\
\mathrm{M} \pm \mathrm{SD}\end{array}$ & & \\
\hline \multirow[t]{5}{*}{$\%$ RVC } & $\begin{array}{l}\text { Deltoid } \\
\text { anterior }\end{array}$ & $94.64 \pm 9.46$ & $92.73 \pm 7.67$ & 1.843 & 0.402 \\
\hline & $\begin{array}{l}\text { Deltoid } \\
\text { posterior }\end{array}$ & $99.97 \pm 15.54$ & $115.23 \pm 12.73$ & -14.948 & $0.000^{*}$ \\
\hline & $\begin{array}{l}\text { Supra } \\
\text { spinatus }\end{array}$ & $99.62 \pm 14.68$ & $100.14 \pm 12.61$ & -0.084 & -0.913 \\
\hline & $\begin{array}{l}\text { Infra } \\
\text { spinatus }\end{array}$ & $122.41 \pm 20.53$ & $94.28 \pm 12.47$ & 24.284 & $0.000^{*}$ \\
\hline & $\begin{array}{l}\text { Trapezius } \\
\text { upper }\end{array}$ & $103.58 \pm 18.44$ & $95.41 \pm 21.57$ & 7.428 & 0.123 \\
\hline \multirow[t]{2}{*}{$\begin{array}{l}\text { Muscle } \\
\text { thickness }\end{array}$} & $\begin{array}{l}\text { Supra } \\
\text { spinatus }\end{array}$ & $50.15 \pm 5.28$ & $63.25 \pm 2.43$ & 13.054 & $0.000^{*}$ \\
\hline & $\begin{array}{l}\text { Infra } \\
\text { spinatus }\end{array}$ & $14.17 \pm 1.97$ & $31.93 \pm 10.36$ & 17.081 & $0.000^{*}$ \\
\hline
\end{tabular}

${ }^{*} p<0.001$
시위근, 가시아래근, 위등세모근 등에서 정규성을 나타내었다(Table 2).

\section{2. 집단 내 실험군 의 \%RVC와 근두께 변화비교}

실험군의 집단 내 \%RVC 변화비교에서는 뒤어깨세모근과 가시아래 근에서 유의한 차이가 있었으며 $(\mathrm{p}<0.001)$, 근두께에서는 가시위근과 가시아래근 모두에서 유의한 차이가 있었다 $(\mathrm{p}<0.001)$ (Table 3$)$.

\section{3. 집단 내 실험군 ॥의 \%RVC와 근두께 변화비교}

실험군 II의 집단 내 \%RVC 변화비교에서는 앞어깨세모근, 뒤어깨세 모근 그리고 가시아래근에서 유의한 차이가 있었으며 $(\mathrm{p}<0.05$, $\mathrm{p}<0.01, \mathrm{p}<0.001)$, 근두께에서는 가시위근과 가시아래근 모두에서 유 의한 차이가 있었다 $(\mathrm{p}<0.001)$ (Table 4$)$.

\section{4. 집단 간 \%RVC와 근두께 변화비교}

집단 간 \%RVC의 변화비교에서는 뒤어깨세모근에서만 유의한 차이 가 있었고 $(\mathrm{p}<0.001)$, 근두께에서는 유의한 차이가 없었다(Table 5).

\section{고 찰}

수술 후 재활의 목적은 질환의 상태를 이해하여 추가손상을 방지하 고, 교원질의 회복을 도모하며 약해진 근력을 강화시켜 유착, 구축 등 에 의해 감소된 관절운동을 회복하는 것이지만 봉합부위와 힘줄을 복원한 부위를 고려해서 적용해야 한다. ${ }^{16}$ 어깨 돌림근띠 복원술 후 어깨 돌림근띠의 기능이 소실된 상태에서는 어깨세모근의 대상성 흥 분으로 인해 어깨뼈의 관절오목에 대한 위팔뼈의 위쪽으로 향하는 압력이 발생하고 이 때문에 정상적인 움직임이 어려워지게 된다.22 이

Table 4. Change in \%RVC and muscle thickness within experimental group II

\begin{tabular}{|c|c|c|c|c|c|}
\hline & & \multicolumn{2}{|c|}{ Experimental group $\|(n=15)$} & \multirow[b]{2}{*}{$\mathrm{t}$} & \multirow[b]{2}{*}{$\mathrm{p}$} \\
\hline & & $\begin{array}{l}\text { pre-test } \\
\mathrm{M} \pm \mathrm{SD}\end{array}$ & $\begin{array}{l}\text { post-test } \\
M \pm S D\end{array}$ & & \\
\hline \multirow[t]{5}{*}{$\% \mathrm{RVC}$} & $\begin{array}{l}\text { Deltoid } \\
\text { anterior }\end{array}$ & $100.79 \pm 15.46$ & $87.53 \pm 22.71$ & 12.897 & $0.032^{*}$ \\
\hline & $\begin{array}{l}\text { Deltoid } \\
\text { posterior }\end{array}$ & $110.64 \pm 18.25$ & $93.74 \pm 14.26$ & 15.492 & $0.008^{* *}$ \\
\hline & $\begin{array}{l}\text { Supra } \\
\text { spinatus }\end{array}$ & $106.76 \pm 12.38$ & $101.64 \pm 18.49$ & 5.087 & 0.242 \\
\hline & $\begin{array}{l}\text { Infra } \\
\text { spinatus }\end{array}$ & $128.98 \pm 23.41$ & $98.41 \pm 12.23$ & 28.252 & $0.000^{* * *}$ \\
\hline & $\begin{array}{l}\text { Trapezius } \\
\text { upper }\end{array}$ & $105.08 \pm 20.18$ & $94.28 \pm 21.52$ & 10.897 & 0.053 \\
\hline \multirow{2}{*}{$\begin{array}{l}\text { Muscle } \\
\text { thickness }\end{array}$} & $\begin{array}{l}\text { Supra } \\
\text { spinatus }\end{array}$ & $50.12 \pm 6.40$ & $65.43 \pm 3.89$ & 14.842 & $0.000^{* * *}$ \\
\hline & $\begin{array}{l}\text { Infra } \\
\text { spinatus }\end{array}$ & $14.03 \pm 2.26$ & $34.09 \pm 3.47$ & 20.428 & $0.000^{* * *}$ \\
\hline
\end{tabular}


Table 5. Change in \%RVC and muscle thickness between experimental groups

\begin{tabular}{|c|c|c|c|c|c|c|}
\hline & & Group & Pre & Post & $\mathrm{F}$ & $\mathrm{p}$ \\
\hline \multirow[t]{10}{*}{ \%RVC } & \multirow[t]{2}{*}{ Deltoid anterior } & Experimental group I & $94.64 \pm 9.46$ & $92.73 \pm 7.67$ & \multirow[t]{2}{*}{8.243} & \multirow[t]{2}{*}{0.067} \\
\hline & & Experimental group II & $100.79 \pm 15.46$ & $87.53 \pm 22.71$ & & \\
\hline & \multirow[t]{2}{*}{ Deltoid posterior } & Experimental group I & $99.97 \pm 15.54$ & $115.23 \pm 12.73$ & \multirow[t]{2}{*}{26.489} & \multirow[t]{2}{*}{$0.000^{*}$} \\
\hline & & Experimental group II & $110.64 \pm 18.25$ & $93.74 \pm 14.26$ & & \\
\hline & \multirow[t]{2}{*}{ Supra spinatus } & Experimental group I & $99.62 \pm 14.68$ & $100.14 \pm 12.61$ & \multirow[t]{2}{*}{1.842} & \multirow[t]{2}{*}{0.832} \\
\hline & & Experimental group II & $106.76 \pm 12.38$ & $101.64 \pm 18.49$ & & \\
\hline & \multirow[t]{2}{*}{ Infra spinatus } & Experimental group I & $122.41 \pm 20.53$ & $94.28 \pm 12.47$ & \multirow[t]{2}{*}{4.825} & \multirow[t]{2}{*}{0.483} \\
\hline & & Experimental group II & $128.98 \pm 23.41$ & $98.41 \pm 12.23$ & & \\
\hline & \multirow[t]{2}{*}{ Trapezius upper } & Experimental group I & $103.58 \pm 18.44$ & $95.41 \pm 21.57$ & \multirow[t]{2}{*}{1.094} & \multirow[t]{2}{*}{0.887} \\
\hline & & Experimental group II & $105.08 \pm 20.18$ & $94.28 \pm 21.52$ & & \\
\hline \multirow[t]{4}{*}{ Muscle thickness } & \multirow[t]{2}{*}{ Supra spinatus } & Experimental group I & $50.15 \pm 5.28$ & $63.25 \pm 2.43$ & \multirow[t]{2}{*}{2.184} & \multirow[t]{2}{*}{0.718} \\
\hline & & Experimental group II & $50.12 \pm 6.40$ & $65.43 \pm 3.89$ & & \\
\hline & \multirow[t]{2}{*}{ Infra spinatus } & Experimental group I & $14.17 \pm 1.97$ & $31.93 \pm 10.36$ & \multirow[t]{2}{*}{2.791} & \multirow[t]{2}{*}{0.684} \\
\hline & & Experimental group II & $14.03 \pm 2.26$ & $34.09 \pm 3.47$ & & \\
\hline
\end{tabular}

${ }^{*} p<0.001$

는 수술 후 기능이 떨어진 어깨 돌림근띠에 의해 나타나는 일반적인 현상으로 수술 후 근력의 회복에 미치는 영향은 파열정도에 따라 다 른 것으로 인식 되었지만, 최근엔 수술 후 어떤 관리를 하느냐에 따라 회복정도는 달라질 것이라는 의견이 지배적이다. ${ }^{23}$

본 연구는 어깨돌림근띠 복원술 후 6 주가 지난 환자를 대상으로 4 주 간 일반적 운동치료 중재와쥐기를 활용한 운동치료 중재를 적용 하여 어깨주변근육의 활성도와 근두께에 미치는 영향을 알아보았으 며, 결과를 토대로 다음과 같이 논의해 보고자 한다. McCully 등 24 은 가시위근의 기능이 떨어진 상태를 재연하기 위해 15 명의 남녀 대상자 로 가시위신경을 신경마취 시키기 전과 후를 비교하였는데, 가시위신 경 마취로 인한 가시위근의 약화 시 어깨세모근들의 근활성도 증가 를 확인 하였다. 어깨충돌증후군 환자나 어깨 돌림근띠 손상환자의 운동치료는 이러한 대상성 움직임을 줄이고 가동화 단계에서 나타 나는 불균형을 정상적으로 되돌리는데 목적이 있다..$^{25}$ 또한 Worsley 등 15 은 정상군 16 명과 어깨충돌증후군을 가진 환자 16 명을 대상으로 10 주 동안 운동조절 재훈련을 시켜 표면근전도와 Vicon 3차원 동작 분석기를 사용하여 관절기능과 어깨 주변근육의 활성도 및 생역학 적 분석을 한 실험에서 어깨뼈의 운동학적 측면과 연관된 어깨근육 들이 변화되는 것을 확인 하였다. 그리고 Roy 등 ${ }^{26}$ 의 연구에서도 33 명 의 어깨끼임 증후군 환자들에게 뻗기 동작을 훈련시킨 결과 어깨에 적용한 운동 중재가 어깨의 끼임 증후군을 완화 시켰다고 하였고, 이 는 운동 중재가 어깨의 근육동원 패턴을 변화 시켰기 때문이라고 하 였다. 본 연구에서도 실험군 집단 내 \%RVC의 변화 비교에서는 실험 군의 경우 뒤어깨세모근은 중재 후 증가하였고 가시아래근은 \%RVC 가 감소하여 유의한 차이를 나타냈으며, 실험군II의 경우 앞어깨세모 근, 뒤어깨세모근 그리고 가시아래근 모두 \%RVC가 감소하여 수술
후 정상적인 어깨움직임을 방해하는 대상성 움직임이 쥐기를 활용 한 운동을 통해서 어느 정도 억제된 것으로 나타났다. 그러나 실험군 I의 뒤어깨세모근의 증가는 중재 후 여전히 남아있는 어깨세모근의 대상성 흥분을 반영하는 것이라 할 수 있다.

어깨관절의 초기 움직임 시에 가시위근은 특히 $30^{\circ}$ 미만에서 높은 활성도를 보인다. ${ }^{27}$ 가시위근은 어깨 돌림근띠 손상 중 손상률이 $95 \%$ 이상으로 가장 높은 손상빈도를 보이며, 가시아래근이나 어깨밑근 이 다음으로 높은 손상빈도를 보이고 있다. ${ }^{28}$ 또한 Struyf 등 29 은 어깨 의 끼임증후군 환자들을 대상으로 연구된 12 개의 논문들을 중심으 로 리뷰논문을 작성하였는데, 위등세모근의 활성도가 비정상적으로 높아져 있음을 보고 하였다. 특히 아래등세모근의 활성도가 떨어지 는 현상을 보이는 사람들에게서 위등세모근은 흔히 지나친 활성도 를 가지게 된다. 위등세모근의 높은 활성도는 가슴우리에서 빗장뼈 의 지나친 올림을 야기하고 어깨뼈의 앞쪽기울기를 발생시켜 어깨위 팔관절의 올림 시에 어깨의 충돌 증상을 만들어낸다. ${ }^{30}$ 위등세모근은 어깨의 기능장애가 발생되어 어깨관절의 원할한 움직임이 일어나지 않을 때 어깨세모근과 더불어 대상작용으로 가장 많이 동원되는 근 육 중 하나이다.22 Jang 드이은 두 가지 팔의 각도와 네 가지 쥐기 강도 로 어깨근육들의 근활성도를 알아본 실험에서 손 쥐기 자세를 중립 자세에서 실시할 경우 가시아래근이 활성화 되고, 팔 $70^{\circ}$ 거상 자세에 서는 어깨세모근이 억제된다는 것을 발견하였다. Antony 와 Keir18의 연구에서도 16 명의 대상자로 어깨의 등척성 수축과 동적 수축을 하 는 동안에 $30 \%$ 쥐기와 손에 $0.5 \mathrm{~kg}$ 의 무게를 든 상태, 그리고 하중이 손에 없는 경우로 각각 8 개 근육의 근활성도를 측정한 결과 특히 가 시아래근의 활성도가 $2 \%$ 정도 증가 했으나 아직 정확한 기전은 밝혀 진바 없다고 하였다. 또한 Sporrong 등ㄹㅇㅔ 따르면 정적인 쥐기를 통해 
세모근의 최대 근활성도가 4-14\% 정도 줄어든다고 하였으며, Hodder 와 $\operatorname{Keir}^{33}$ 의 연구에서도 앞어깨세모근의 경우 쥐기를 여러 차례 반복 하면 활성도가 떨어진다는 것을 발견하였다. 본 연구 결과에서도 실 험군 집단 간 \%RVC의 변화 비교에서 실험군 $\mathbb{I}$ 의 뒤어깨세모근만이 통계학적으로 유의한 차이를 보였으며, 쥐기를 활용한 운동치료 그 룹에서 뒤어깨세모근의 근활성도의 감소가 더 많이 나타나 선행연 구들을 지지하였다. 이는 쥐기를 활용한 운동치료가 어깨세모근의 대상성 움직임을 억제하는데 좀더 효과적이었다는 것을 나타내는 결과라고 할 수 있을 것이다. 이처럼 집단 간 비교에서 유의한 차이가 뒤어깨세모근에서만 나타난 이유는 집단 내 비교와 마찬가지로 $\% \mathrm{RVC}$ 를 측정하는 자세가 어깨관절 $90^{\circ}$ 굽힘 상태에서 실시했기 때 문이라고 사료된다. ${ }^{19}$ 또한 본 연구결과에서 통계학적으로 유의한 차 이는 나타나지 않았으나 두 집단 모두에서 전체적으로 \%RVC가 감소 한 양상을 보였는데, 검사방법에서 어깨의 직접적인 운동 하에서의 측정이 아닌 최대쥐기를 시행하는 동안 측정된 어깨 근육들의 간접 적인 \%RVC이기 때문에 나타난 결과라고 추측된다.

Oschman 등 ${ }^{34}$ 은 15 명의 어깨 돌림근띠 파열환자들을 대상으로 가 시위근과 등세모근을 측정하였는데 검사 결과 파열정도가 증상이 없는 파열 군보다 파열정도가 더 컸음을 발견하였고 가시위근에 위 축이 나타났다고 제시하였다. Myung ${ }^{35}$ 의 연구에서도 어깨 돌림근띠 환자들을 대상으로 8 주 간 슬링을 이용한 운동치료와 일반적 운동치 료를 비교한 실험에서 두 그룹 모두 8 주 후에 가시위근과 가시아래근 의 유의한 근 두께 변화를 나타낸다고 보고 하였다. 본 연구에서도 실 험군 집단 내 근두께 변화 비교에서 가시위근, 가시아래근은 실험군 모두에서 통계학적으로 유의한 차이가 나타나 위의 연구들을 지지 하였다. 그러나 실험군 집단 간 근두께 변화 비교에서 가시아래근만 이 통계학적으로 유의한 차이가 있었다. 가시아래근의 경우 실험군II 에서 근 두께가 더 커진 것으로 나타났는데 이는 쥐기를 활용한 운동 이 가시아래근의 선택적 강화에 효과가 있음을 의미하는 것이다.17

본 연구를 통해서 일반적 운동치료 중재와 쥐기를 활용한 운동치 료 중재는 어깨돌림근띠 복원술 환자들의 어깨주변 근활성도 및 근 두께에 영향을 준다는 것을 알 수 있었다. 특히 쥐기를 활용한 운동치 료 중재는 가시위근과 가시아래근 같은 어깨 안정화 근육들과 수술 후 재활기간에 나타나는 어깨세모근의 증가된 근활성도를 진정시켜 긍정적인 영향을 미친다는 것을 알 수 있었다. 본 연구의 제한점으로 는 단일 의료기관에서 실험을 진행했다는 것과 환자들의 약물과 일 상생활을 통제하지 못하여 결과에 따른 변수가 발생될 수 있다는 점 이며, 근활성도 측정 동작이 직접적인 어깨 움직임이 아닌 최대쥐기 를 통한 간접적인 측정방법이라는 점과 중재기간이 짧고 남자환자들 만을 대상으로 하여 일반화하기에는 어려움이 따른다. 하지만 어깨 재활에 있어 안정성에 관계된 어깨돌림근띠 근육들의 선택적 근력강
화는 기능적인 어깨 움직임에 필요한 임상적 기초자료로써 중요한 요소이고, 그렇기 때문에 앞으로도 지속적으로 연구되어야 할 과제 이며 어깨관절움직임의 다양성만큼 다각적인 시도가 필요할 것이다.

\section{REFERENCES}

1. Sokk J, Gapeyeva H, Ereline J et al. Shoulder muscle function in frozen shoulder syndrome patients following manipulation under anesthesia: A 6-month follow-up study. Orthop Traumatol Surg Res. 2013;99(6): 699-705.

2. Song HS, Kim SY. Comparison of the rehabilitation program after rotator cuff repair by time closed chain exercise. J Korean Soc Phys Med. 2014;9(4):485-92.

3. Wiliams GR, Rockwood CA, Bigliani LU et al. Rotator cuff tears: why do we repair them?. J Bone Joint Surg Am. 2004;86-A(12):2764-76.

4. Seitz AL, McClure PW, Finucane S et al. Mechanisms of rotator cuff tendinopathy: intrinsic, extrinsic, or both?. Clin Biomech, 2011;26(1):1-12.

5. Maxwell CP, James ET, Thay QL. History, physical examination, radiographic anatomy, and biomechanics and physiological function of the rotator cuff. Oper Tech Sports Med. 2012;20(3):201-6.

6. Kim YK. Controversy in pathophysiology of rotator cuff tear: degenerative tear. CiSE. 2008;11(2):71-6.

7. Oliva F, Osti L, Padulo, J et al. Epidemiology of the rotator cuff tears: a new incidence related to thyroid disease. Muscles Ligaments Tendons J. 2014;4(3):309.

8. Papadopoulos P, Karataglis D, Boutsiadis A et al. Functional outcome and structural integrity following mini-open repair of large and massive rotator cuff tears: a 3-5 year follow-up study. J Shoulder Elbow Surg. 2011;20(1):131-7.

9. McKee MD, Yoo DJ. The effect of surgery for rotator cuff disease on general health status. Results of a prospective trial. J Bone Joint Surg Am, 2000;82-A(7):970-9.

10. Namdari S, Green A. Range of motion limitation after rotator cuff repair. J Shoulder Elbow Surg, 2010;19(2):290-6.

11. Huberty DP, Schoolfield JD, Brady PC et al. Incidence and treatment of postoperative stiffness following arthroscopic rotator cuff repair. Arthroscopy. 2009;25(8):880-90.

12. Seo BD, Shin HS. The effect of self-stretching exercise in patients with shoulder adhesive capsulitis. J Kor Soc Phys Ther. 2010;22(1):19-26

13. Kibler WB, McMullen J, Uhl T. Shoulder rehabilitation strategies, guidelines, and practice. Orthop Phys Ther Clin N Am. 2001;32(3):527-38.

14. Yoon HY, Choi JD. Effects of Low-intensity Scapular Stabilization Exercise in Arthroscopic Shoulder Surgery Patients. J Kor Soc Phys Ther. 2012;24(3):229-34.

15. Worsley P, Warner M, Mottram S et al. Motor control retraining exercises for shoulder impingement: effects on function, muscle activation, and biomechanics in young adults. J Shoulder Elbow Surg. 2013;22(4):11-9.

16. Kim jH. Rehabilitation of rotator cuff repair. The Korean Journal of Arthroscopy Soc. 2008;12(2):82-6.

17. Kang JI, Moon YJ, Park sk et al. Effects of exercise program intervention on muscle activity in rotator cuff repair patient. J Kor Soc Phys Ther. 2013;25(2):56-63.

18. Antony NT, Keir PJ. Effects of posture, movement and hand load on 
shoulder muscle activity. J Electromyogr Kinesiol. 2010;20:191-8.

19. Choi H. The effect of hand grip force on the activity of shoulder muscles in the patterns of arm position. Journal of Digital Convergence. 2012; 10(9):435-41.

20. Smets MP, Potvin JR, Keir PJ. Constrained handgrip force decreases upper extremity muscle activation and arm strength. Ergonomics. 2009; 52(9):1144-52.

21. Juul-Kristensen B, Bojsen-Møller F, Holst E et al. Comparison of muscle sizes and moment arms of two rotator cuff muscles measured by ultrasonography and magnetic resonance imaging. Eur J Ultrasound. 2000; 11(3):161-73.

22. Steenbrink F, Nelissen RG, Meskers CG et al. Teres major muscle activation relates to clinical outcome in tendon transfer surgery. Clin Biomech. 2010;25(3):187-93.

23. Lee SY, Gong WT, Park MC et al. A study of shoulder stabilizer muscle exercise using the contraction of finger flexor muscle. J Phys Ther Sci. 2011;23:41-3.

24. McCully SP, Suprak DN, Kosek P et al. Suprascapular nerve block results in a compensatory increase in deltoid muscle activity. J Biomech. 2007; 40(8):1839-46.

25. Cuff DJ, Pupello DR. Prospective randomized study of arthroscopic rotator cuff repair using an early versus delayed postoperative physical therapy protocol. J Shoulder Elbow Surg. 2012;21(11):1450-5.

26. Roy JS, Moffet H, Hébert LJ et al. Effect of motor control and strengthening exercises on shoulder function in persons with impingement syndrome: a single-subject study design. Man Ther. 2009;14(2):180-8.
27. Alpert SW, Pink MM, Jobe FW et al. Electromyographic analysis of deltoid and rotator cuff function under varying loads and speeds. J Shoulder Elbow Surg. 2000;9(1):47-58.

28. Braddom RL, R.M. Buschbacher. Physical medicine and rehabilitation. 2nd, W.B. Saunders Company, 2002.

29. Struyf F, Cagnie B, Cools A et al. Scapulothoracic muscle activity and recruitment timing in patients with shoulder impingement symptoms and glenohumeral instability. J Electromyogr Kinesiol. 2014;24(2):277-84.

30. De Mey K, Danneels L, Cagnie B et al. Kinetic chain influences on upper and lower trapezius muscle activation during eight variations of a scapular retraction exercise in overhead athletes. J Sci Med Sport. 2013;16(1): 65-70.

31. Jang HJ, Kim JS, Choi JD et al. The effects of hand grip force on shoulder muscle activity in two arm posture. JKAIS. 2012;13(3):1229-37.

32. Sporrong H, Palmerud G, Herberts P. Hand grip increases shoulder muscle activity, An EMG analysis with static hand contractions in 9 subjects. Acta Orthop Scand Suppl. 1996;67(5):485-90.

33. Hodder JN, Keir PJ. Targeted gripping reduces shoulder muscle activity and variability. Electromyogr Kinesiol. 2012;22(2):186-90.

34. Oschman Z, Janse van Rensburg C, Maritz NGJ et al. Ultrasound study of the asymptomatic shoulder in patients with a confirmed rotator cuff tear in the opposite shoulder. South African Sports Medicine Assoc. 2007;19(1):23-8.

35. Myung MS. The effect of sling exercises on increase muscles' thickness, function, and range of motion in rotator cuff surgery patients. Junnam University. Dissertation of Master's Degree. 2013. 